\title{
Development of a Polymer Electrolyte Fuel Cell Dead-Ended Anode Purge Strategy for use with a Nitrogen-containing Hydrogen Gas Supply
}

Tonny I. Okedi ${ }^{1}, \quad$ Quentin Meyer ${ }^{1}, \quad$ Hazel M.A. Hunter ${ }^{2 *}$, Paul R. Shearing ${ }^{1}$, Dan J.L. Brett ${ }^{1 *}$

${ }^{1}$ Electrochemical Innovation Lab, Department of Chemical Engineering, UCL, London, WC1E 7JE, UK.

${ }^{2}$ ISIS Facility, STFC Rutherford Appleton Laboratory, Harwell Campus, Didcot, Oxfordshire, OX11 0QX, UK.

* Authors to whom correspondence should be addressed

Email: hazel.hunter@stfc.ac.uk, Tel.: +44(0)1235 445116

Email: d.brett@ucl.ac.uk,Tel.: +44(0)20 76793310

Web: www.ucl.ac.uk/electrochemical-innovation-lab

\section{Graphical Highlight}

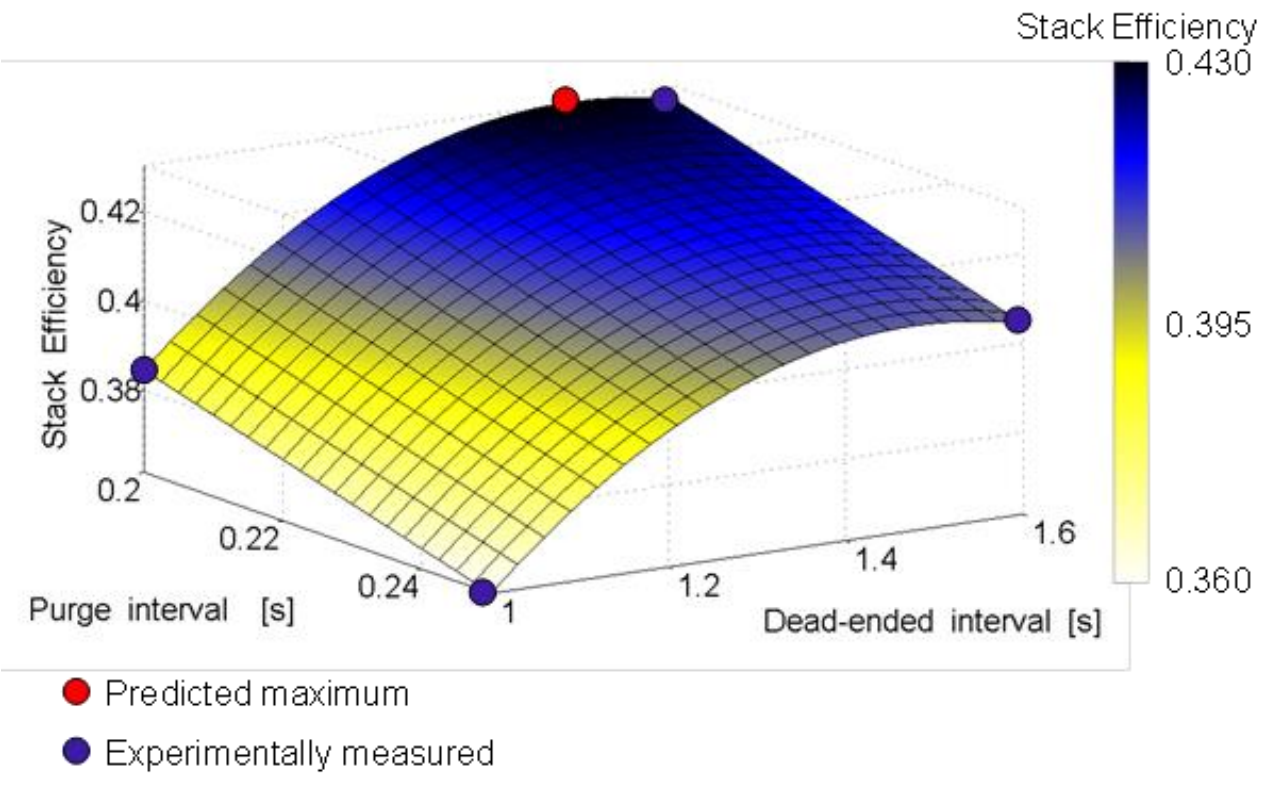


Highlights ( $<85$ characters per highlight; $3-5$ highlights needed)

- Nitrogen-containing hydrogen gas mix supplied to PEFC dead-ended anode.

- Voltage decay seen as both nitrogen content in fuel and fuel cell load increase.

- Design of Experiments methodology used to assess stack efficiency.

- Optimised purge strategy identified for nitrogen-containing hydrogen fuel.

\section{Abstract}

The effect of nitrogen content within the hydrogen fuel supplied to a polymer electrolyte fuel cell (PEFC) operating in dead-ended anode mode is examined, with a view to using an ammonia decomposition product gas mix (containing $75 \mathrm{H}_{2}: 25 \mathrm{~N}_{2}$ ) as the hydrogen-containing fuel. The impact of this impure hydrogen stream, supplied to the anode, was evaluated in terms of mean cell voltage and in relation to actual operating conditions (purge interval, dead-ended interval and fuel cell load). Design of Experiments (DoE) methodology, using multi-linear models, assessed hydrogen utilisation in terms of stack efficiency and identified an effective and viable dead-ended anode purge strategy for this nitrogen-containing hydrogen fuel.

\section{Keywords}

Ammonia; Purge strategy; Dead-ended anode; Design of Experiments; Hydrogen; Nitrogen.

\section{Introduction}

\subsection{Hydrogen, ammonia and fuel cells}

In the search for alternatives to fossil fuels, hydrogen, $\mathrm{H}_{2}$, is an attractive energy carrier given its high gravimetric energy density $\left(120 \mathrm{MJ} \mathrm{kg}^{-1}\right)$. However, its use as a fuel generates a number of concerns, not least the high pressures ( 700 bar) or complex cryogenic systems needed to store the gas in reasonable volumes, due to its low 
volumetric energy density, and the corresponding safety apprehensions associated with the transport and use of a pressurised flammable gas. Consequently, in recent years, hydrogen storage research has focused on chemical storage methods to identify potential materials which exhibit both high gravimetric and volumetric $\mathrm{H}_{2}$ densities [1, 2].

The ammonia molecule, $\mathrm{NH}_{3}$, contains $17.8 \mathrm{wt} \%$ hydrogen and, like $\mathrm{H}_{2}$, is carbon-free at point of use. It is easily liquefied at ambient temperatures and modest pressures (8-10 bar), and has a volumetric $\mathrm{H}_{2}$ density of $121 \mathrm{kgH}_{2} \mathrm{~m}^{-3}$ (when liquid). Furthermore, the numerous industrial uses of ammonia, for example in fertilizer manufacture or in refrigeration, mean that a global ammonia transportation infrastructure already exists and that the handling and safety protocols are well established. Thus, ammonia is a promising hydrogen storage candidate if its intrinsic hydrogen content can be accessed for use.

Several techniques can be used to decompose ammonia to release the hydrogen contained within. In the field of catalysis, traditional ammonia decomposition catalysts use expensive transition metals (e.g. $\mathrm{Ru}, \mathrm{Ni}$ ) loaded on to high surface area support materials. Recently, however, a new class of inexpensive catalyst has been identified [3-5], based upon light metal amides and imides, which is able to effectively decompose ammonia to its constituents, hydrogen and nitrogen, at atmospheric pressure and at moderate temperatures (Equation 1):

$$
2 \mathrm{NH}_{3} \rightarrow 3 \mathrm{H}_{2}+\mathrm{N}_{2} \quad \Delta \mathrm{h}_{\mathrm{f}}=46 \mathrm{~kJ} \mathrm{~mol}^{-1}
$$

Significantly, this decomposition reaction produces no greenhouse gases or atmospheric pollutants $\left(\mathrm{CO}_{\mathrm{x}}, \mathrm{SO}_{\mathrm{x}}\right.$ or $\left.\mathrm{NO}_{\mathrm{x}}\right)$. When the ammonia decomposition reaction is taken to completion, the product gas is a mixture of hydrogen and nitrogen in a welldefined 3:1 (or $75 \%: 25 \%$ ) $\mathrm{H}_{2}: \mathrm{N}_{2}$ mole ratio. Such a gas composition has implications for the downstream use of this hydrogen-containing fuel.

Fuel cells are attractive alternative energy sources, given their zero-carbon emissions at point of use. These efficient electrochemical devices convert chemical energy to 
electrical energy, using a fuel (typically $\mathrm{H}_{2}$ ) and an oxidant (typically $\mathrm{O}_{2}$ in air), and are being considered for a broad range of applications including those of portable, stationary and automotive power supply. Of particular interest to this study are low temperature, high efficiency fuel cell stacks which, when assembled in a fully insulated system, have the potential to deliver net efficiency gains. Specifically, the two relevant types are alkaline fuel cells (AFCs) and polymer electrolyte fuel cells (PEFCs). AFCs are partially ammonia compatible [4], and have a long development history [5] having been used on the Apollo space missions; in spite of this, they are not widely commercially available. Consequently, a PEFC was selected for this work as it is considered the leading low temperature power-generating technology for use with hydrogen fuel, can be bought off-the-shelf. However, PEFCs are designed to operate with a high purity (>99.995\%) $\mathrm{H}_{2}$ gas supply to the anode. By the very nature of the decomposed ammonia product gas mix containing $25 \% \mathrm{~N}_{2}$, and with hydrogennitrogen separation methods being prohibitive in terms of both pressure requirements and cost, there are significant operational challenges that need to be overcome if an impure hydrogen supply is to be used as the fuel for a PEFC. Here, we address these challenges, and aim to identify a PEFC purge strategy suitable for use with a hydrogen gas stream containing up to $25 \% \mathrm{~N}_{2}$.

A schematic overview of the whole process is shown in Fig. 1, with the red inner box highlighting the work under consideration here.

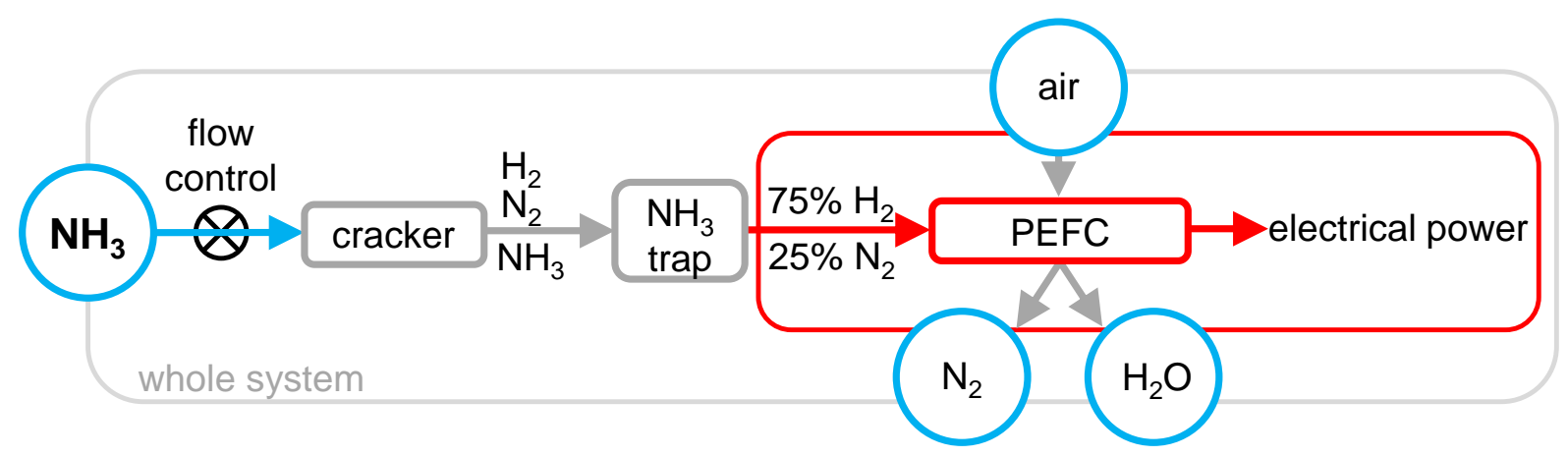

Fig. 1. Schematic of ammonia-hydrogen-PEFC system, highlighting (in red) the fuel cell purge strategy component under consideration.

\subsection{Dead-ended anode operation}


A simple calculation using the Nernst equation, that takes into account the reduced hydrogen partial pressure as a result of the $25 \% \mathrm{~N}_{2}$ gas content, indicates [6] that there is only very minor impact $(<0.3 \%)$ upon the maximum possible open-circuit voltage of the whole stack. This demonstrates that it should theoretically be possible to operate a PEFC with a $75 \mathrm{H}_{2}: 25 \mathrm{~N}_{2}$ gas mix, however, there are some additional concerns, especially when the fuel cell is operated in dead-ended anode mode.

Dead-ended anode (DEA) operation is a common method [7, 8] for operating PEFCs as it can simplify the fuel cell system design, potentially avoiding flow meters, humidifiers, and huge hydrogen losses (slippage) if recirculation is not used. It employs a single pressure regulator before the gas inlet to the stack and a purge valve after the anode outlet. However, when operating in dead-ended mode, performance decay can occur (even when using $100 \% \mathrm{H}_{2}$ ) and intermittent purging of the anode chamber is required to replenish the hydrogen fuel supply and thus sustain effective operation. This gradual voltage loss has been measured and modelled [8-12], highlighting the influence of several factors. Nitrogen cross-over from cathode to anode (the permeation factor where $\mathrm{N}_{2}$ is derived from the air) is of particular relevance and has been shown to increase with increasing current density and temperature [10, $13,14]$. It leads to nitrogen 'blanketing', where $\mathrm{N}_{2}$ accumulates in the centre of anode cells, thereby blocking $\mathrm{H}_{2}$ access to the active surface [15]. Within the anode flowfield, water has been shown, by neutron imaging $[16,17]$ and by the use of a transparent cell [18], to accumulate towards the exhaust ends of the cells. However, very few groups have considered the optimisation of dead-ended anode operation using diluted hydrogen feedstocks. Specifically Nachiappan et al. [19] considered the impact of dilution with $\mathrm{CO}_{2}$ or $\mathrm{N}_{2}$ impurities upon the polarisation curve, while Um et al. [20] used computational fluid dynamics modelling to explore the hydrogen dilution effects of reformate gas (containing $\mathrm{CO}_{2}$ and $\mathrm{N}_{2}$ ) yet neither of these studies reported voltage degradation. Additionally, only one other study by Yu et al. [21] has examined the role of nitrogen in the hydrogen gas stream supplied to the anode, and even then Yu et al. only considered a $99.2 \mathrm{H}_{2}: 0.8 \mathrm{~N}_{2}$ gas mix. Therefore, this work aims to extend our knowledge of the impact of nitrogen within the hydrogen (anode) fuel stream in order to design a relevant purge strategy for the ammonia decomposition product gas mix that could give insight into the applicability of combining an ammonia cracking system with a PEFC. Furthermore, in DEA mode, the $\mathrm{N}_{2}$ dilution effect is amplified 
with time, thus as the hydrogen supply is consumed, the passive nitrogen gas becomes more concentrated as it cannot leave the anode chamber. The approach adopted here aims to minimise any voltage loses to avoid irreversible damage to the cell whilst also limiting any fuel loses due to excessive purging. In other words, this task must identify a balance between the dead-ended interval (when the purge valve is closed) and the purge interval (when the purge valve is open), with respect to current density, to deliver an optimised fuel cell system.

\subsection{Design of Experiment methodology}

In practice, individual fuel cell systems will require specifically tuned operating conditions. An effective way of identifying a suitable dead-ended anode purge strategy is to use the Design of Experiment (DoE) methodology. This creates a factorial experimental plan which increases productivity by both minimising the number of test runs required and also maximising the accuracy of the results obtained [22, 23]. As fuel cells have a wide range of component options and operating conditions, DoE has been used extensively for analysis of material properties [24], improvement of bipolar plate design [25, 26], and optimisation of membrane electrode assembly composition $[27,28]$ (including membrane type, platinum loading, Nafion impregnation in the electrode and gas diffusion layer assessment). DoE has also been used to improve the performance of fuel cell systems by maximising the power output and overall system efficiency [29-31].

This work identifies the baseline PEFC performance using both pure $\mathrm{H}_{2}$ (denoted $100 \% \mathrm{H}_{2}$ ) and variable $\mathrm{H}_{2}: \mathrm{N}_{2}$ feed gas compositions (denoted $x \mathrm{H}_{2}: y \mathrm{~N}_{2}$ where $x$ and $y$ vary between $95 \%-75 \%$ and $5 \%-25 \%$, respectively). Once the baseline performance was understood, in both through-flow and dead-ended anode mode, the DoE methodology was employed to identify the optimum dead-ended anode operational conditions to maximise the stack efficiency, minimise long term stack degradation, and thus determine an optimised purge strategy with the most suitable current density, dead-ended interval and purge interval for a $75 \mathrm{H}_{2}: 25 \mathrm{~N}_{2}$ gas feed.

\section{Experimental}


A Horizon Fuel Cell Technologies Pte Ltd $\mathrm{H}-100$ 20-cell air-cooled, open-cathode polymer electrolyte fuel cell was used in this study. This self-humidifying stack has an active cell area of $22.5 \mathrm{~cm}^{2}$ and is able to deliver a maximum power of $100 \mathrm{~W}$. Its membrane electrode assembly is composed of a commercially available gas diffusion layer, a serpentine anode flow-field geometry and has a catalyst coated membrane loaded with platinum at 0.15 and $0.5 \mathrm{mg} \mathrm{cm}^{-2}$ on the anode and cathode, respectively. The fuel cell is connected to a custom-built test station that enables variable composition mixing of dry hydrogen $\left(99.995 \% \mathrm{H}_{2}, \quad B O C\right)$ and dry nitrogen $\left(99.998 \% \mathrm{~N}_{2}, \mathrm{BOC}\right.$ ), using two mass flow controllers (MFC, Bronkhorst EL-FLOW $\mathrm{F}-201 \mathrm{CV}$, maximum flow rate $2000 \mathrm{ml} \mathrm{min}^{-1}$ ), and supplies the desired gas mixture to the anode inlet of the fuel cell stack. This set-up delivers a pressurised stream of mixed $\mathrm{H}_{2}: \mathrm{N}_{2}$ gas at 1.45 bar (i.e. 0.45 bar above atmospheric pressure); however, after initial testing an additional $1 \mathrm{~L}$ buffer volume was added immediately upstream of the fuel cell, to minimise depressurisation of the cell when the anode exhaust purge valve is opened. The exhaust hydrogen flow rate (determined when testing in through-flow mode) was measured using a thermal mass flow meter (MFM, Bronkhorst MassVIEW MV-196-H2, 0.2-100 $\ln \mathrm{min}^{-1}$ ). A blower, which provides cooling and an air supply to the open-cathode channels, was regulated using an Agilent 3649A programmable power supply. The current drawn from the PEFC was controlled using a Kikusui PLZ664WA electronic load operated in galvanostatic mode. A computer system, designed in-house using National Instruments LabVIEW 2012 software, was used to control the cathode air blower, along with the hydrogen and nitrogen MFCs, and electrical valves. In addition, the computer system recorded the voltage of the twenty cells within the stack simultaneously (via a custom-built cell voltage monitoring device connected to two National Instruments USB 6363 DAQ units), and displayed and logged the data in real time. Ambient temperature, absolute pressure and relative humidity $(\mathrm{RH})$ were measured as $21.3 \pm 1^{\circ} \mathrm{C}, 1.03 \pm 0.02$ bar and $31 \% \mathrm{RH}$ respectively, during all tests. A schematic of the experimental set-up is shown in Fig. 2, with a more detailed process and instrumentation diagram available in the Supplementary Information. 


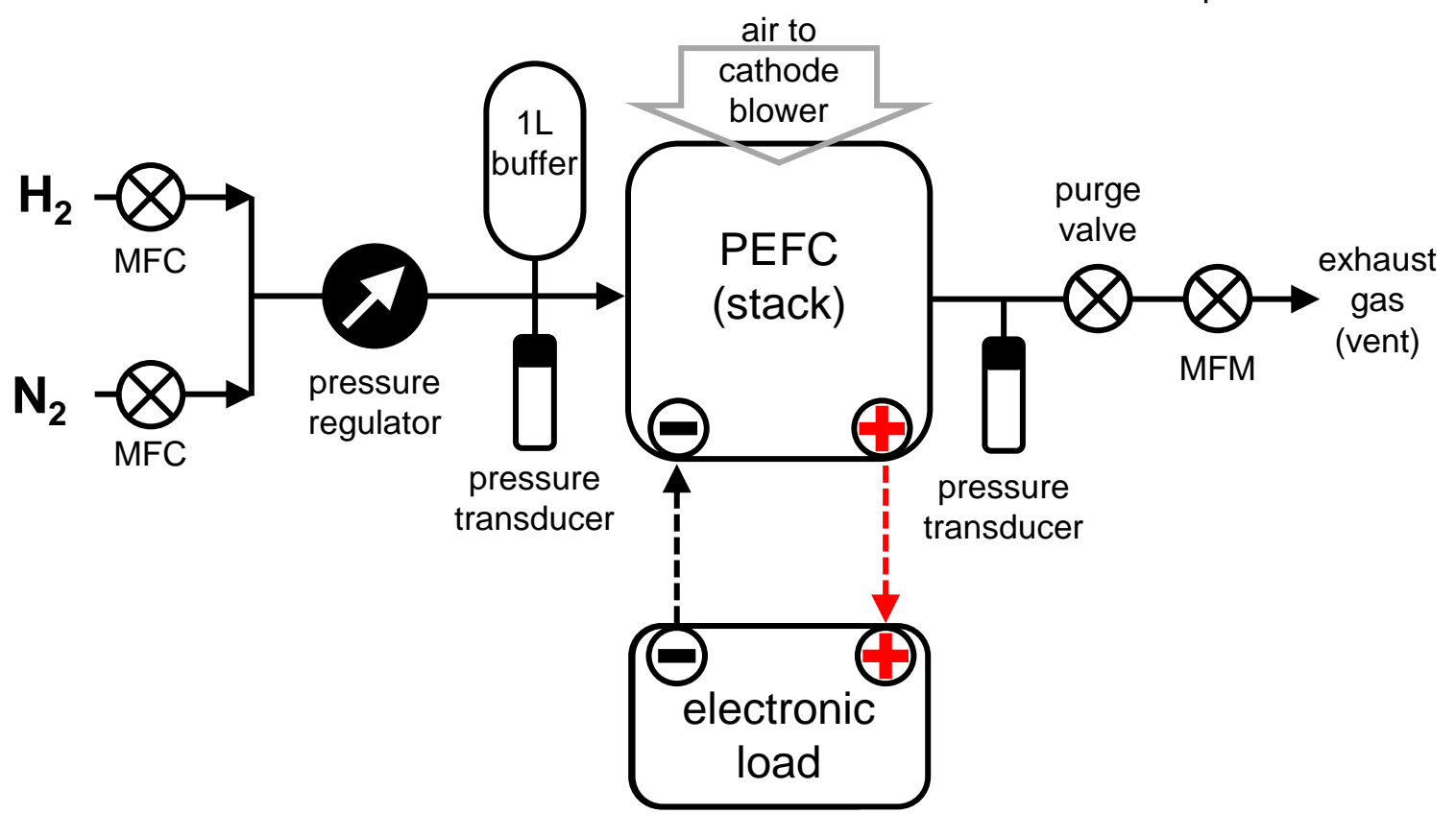

Fig. 2. Overview schematic of the experimental set-up. The operational pressure conditions are shown above; MFC = mass flow controller, MFM = mass flow meter, $\mathrm{PEFC}=$ polymer electrolyte fuel cell (see Supplementary Information for full details).

\section{Results and Discussion}

\subsection{Identifying dead-ended anode performance}

Before implementation of the DoE methodology, an initial series of experiments were undertaken to assess the effect of increasing the $\mathrm{N}_{2}$ content, in the anode gas supply, upon the fuel cell performance. Firstly, in through-flow mode, the current-voltage data was collected using pure $\mathrm{H}_{2}$ whilst increasing the current density in 50 incremental steps between 0.00 and $0.56 \mathrm{~A} \mathrm{~cm}^{-2}$, with a $15 \mathrm{~s}$ dwell at each step. The resultant polarisation curve (Fig. 3a) allows determination of a region of constant change between $0.18 \mathrm{~A} \mathrm{~cm}^{-2}$ and $0.36 \mathrm{~A} \mathrm{~cm}^{-2}$ which is defined as the area of interest for the remaining study. This coincides with the centre of the ohmic region and thus ensures avoidance of mass transport limitations which would negatively impact upon any deadended event $[32,33]$. 

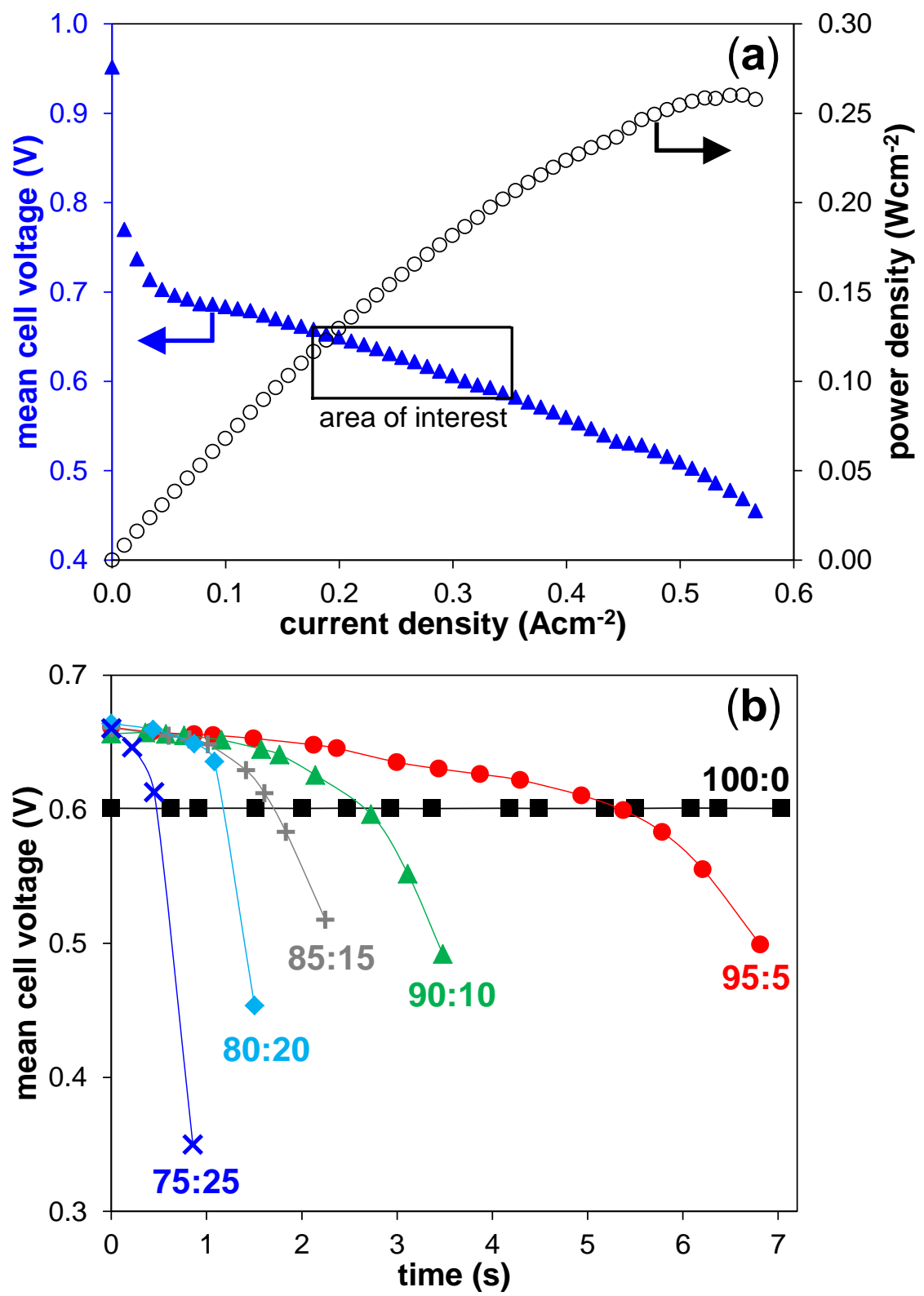

Fig. 3. (a) $\mathrm{H}-100$ polarisation curve obtained using $100 \% \mathrm{H}_{2}$ in through-flow mode (where the area of interest for this study is highlighted) and (b) voltage decay plot for selected $\mathrm{H}_{2}: \mathrm{N}_{2}$ ratios (100:0, 95:5, 90:10, 85:15, 80:20 and 75:25, respectively) collected at $0.36 \mathrm{~A} \mathrm{~cm}^{-2}$ in deadended anode mode without the buffer volume in place.

Secondly, in dead-ended mode, the impact of changing the $\mathrm{H}_{2}: \mathrm{N}_{2}$ ratio on the mean cell voltage was investigated at a constant load of $0.36 \mathrm{~A} \mathrm{~cm}^{-2}$ (Fig. 3b). In this series of tests a steady-state cycle was created where the typical voltage degradation dataset for each $\mathrm{H}_{2}: \mathrm{N}_{2}$ ratio was collected over five "purge-measure" cycles. In order to avoid causing long term damage to the fuel cell stack, purging was triggered when the 
voltage of the poorest performing cell fell below $0.5 \mathrm{~V}$, with the closure of the purge valve corresponding to time $t=0$ and the frequency of the data points limited by the logging speed. An initial observation of these $\mathrm{H}_{2}: \mathrm{N}_{2}$ gas mix datasets shows that the $t=0$ mean cell voltages are $\sim 50 \mathrm{mV}$ greater than that collected using $100 \% \mathrm{H}_{2}$. When using $100 \% \mathrm{H}_{2}$ in through-flow mode the purge valve is always open thus there is never a change in the gas pressure within the stack. By contrast the $\mathrm{H}_{2}: \mathrm{N}_{2}$ gas mix datasets were collected in dead-ended anode mode where the action of closing the purge valve causes a pressure increase within the fuel cell and, as described by the Nernst equation, this translates into a voltage increase at $t=0$. Additionally, as the nitrogen content increases, the rate of voltage decay also increases, indicating that the voltage loss is proportional to $\mathrm{N}_{2}$ accumulation within the fixed volume anode flowfield. Nevertheless, there are two consistent features that transcend the specific $\mathrm{H}_{2}: \mathrm{N}_{2}$ ratio under examination. Specifically, an initial gradual voltage decay from $0.65 \mathrm{~V}$ to $0.60 \mathrm{~V}\left(\sim 10-20 \mathrm{mV} \mathrm{s}^{-1}\right)$ is followed by a more rapid decay below $0.60 \mathrm{~V}$ $\left(\sim 80-500 \mathrm{mV} \mathrm{s}^{-1}\right)$. This behaviour is attributed to nitrogen gradually filling the anode volume, causing initial diffusion limited (slow) voltage loss before hydrogen starvation leads to more rapid loss.

During these initial experiments it became apparent that a buffer volume was required immediately upstream of the fuel cell to dampen the effect that opening/closing the purge valve has upon the gas pressure within the test system. Fig. 4 illustrates this response and shows that after the buffer volume was connected in series the fuel cell performance stabilises and the experimental error between cycles reduces substantially. In the case of the $75 \mathrm{H}_{2}: 25 \mathrm{~N}_{2}$ gas mix at $0.36 \mathrm{~A} \mathrm{~cm}^{-2}$, the steady-state cycle time also extends by $2 \mathrm{~s}$ before the $0.5 \mathrm{~V}$ voltage decay threshold is reached (Fig. 4b). All subsequent dead-ended anode DoE measurements, therefore, were undertaken in the presence of the buffer volume as this allows collection of repeatable datasets and thus reliable evaluation of stack efficiency and power density. 

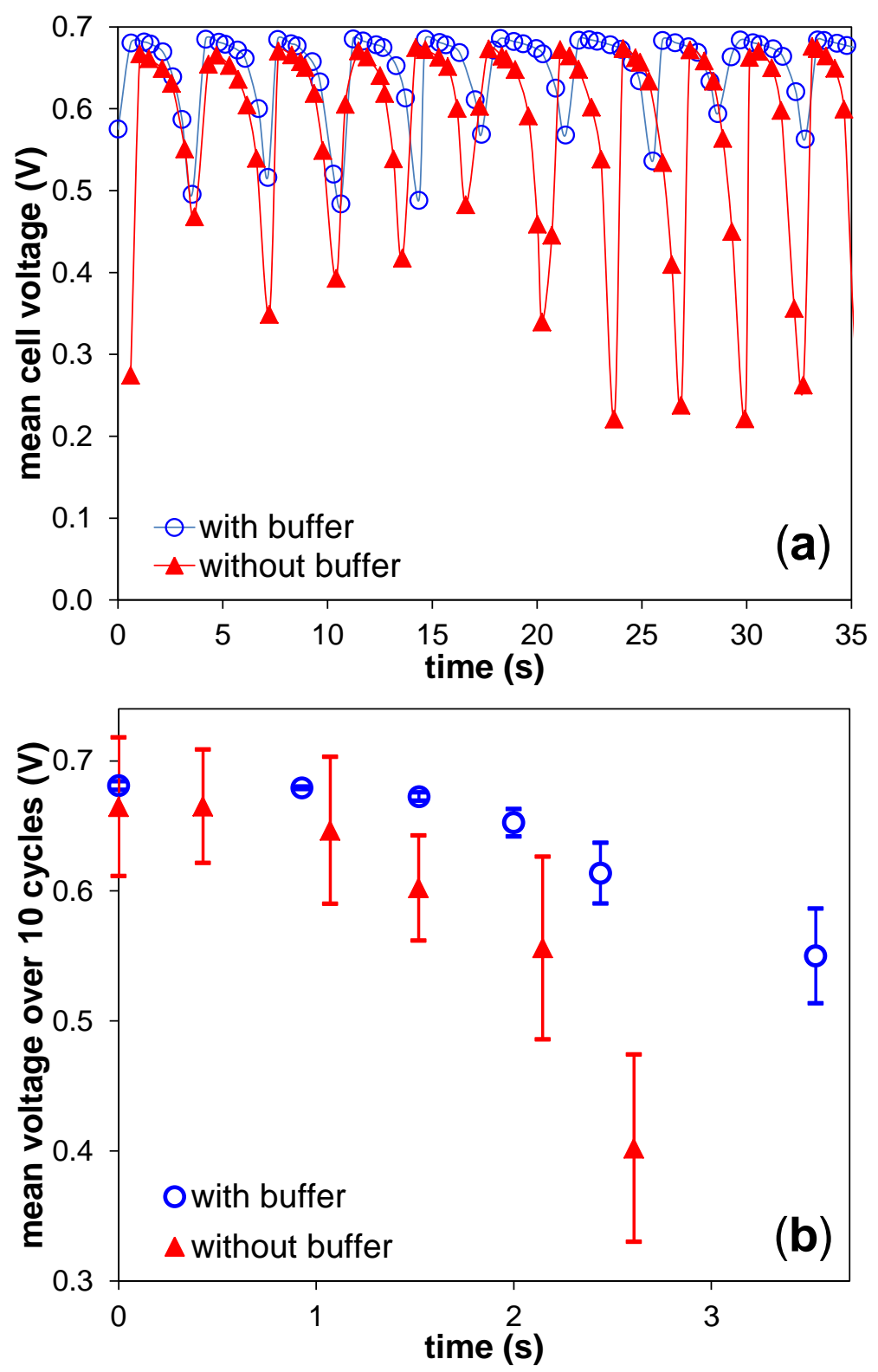

Fig. 4. Recoverable voltage decay plots, with and without the buffer volume in place, for the $75 \mathrm{H}_{2}: 25 \mathrm{~N}_{2}$ gas mix collected at $0.36 \mathrm{~A} \mathrm{~cm}^{-2}$ in dead-ended anode mode showing (a) non-repeatable steady-state cycling and (b) average performance over 10 cycles with corresponding standard deviation errors. 


\subsection{Stack efficiency and power density calculation}

Stack efficiency and power density are two parameters which can be used to evaluate the performance between different dead-ended anode operating conditions during DoE testing. Here, the stack efficiency, $\eta$, is defined according to Chen et al. [9] as follows (Equation 2):

$\eta=\frac{\int_{0}^{\text {tot }} V_{\text {mean cell } j A d t}}{-\sum_{1}^{m} \Delta h_{f}\left(n_{H_{2}}^{\text {consumed }}+n_{H_{2}}^{\text {loss }}\right)}$

where $V_{\text {mean cell }}$ is the mean cell voltage, $j$ the current density, $A$ the electrode crosssectional area, $m$ the number of DEA cycles being considered, tot the total operating time (where $t_{t o t}=m \cdot t_{\text {cycle }}$ and $t_{\text {cycle }}$ the duration of a single DEA cycle), $\Delta h_{f}$ the lower heating value (LHV) enthalpy of formation of $\mathrm{H}_{2}, n_{\mathrm{H}_{2}}^{\text {consumed }}$ the number of moles of hydrogen consumed, and $n_{\mathrm{H}_{2}}^{\text {loss }}$ the number of moles of hydrogen lost (i.e. the amount of un-used hydrogen that is vented during a purge).

The amount of hydrogen consumed, $n_{\mathrm{H}_{2}}^{\text {consumed }}$, during a DEA cycle is obtained using Faraday's law for a given current density and cycle duration (Equation 3):

$n_{H_{2}}^{\text {consumed }}=\frac{j A}{n_{e}\left(H_{2}\right) F} t_{c y c l e}$

Meanwhile, a calculation of the hydrogen lost, $n_{H_{2}}^{\text {loss }}$, also needs to account for the amount of nitrogen inside the anode flow-field. Indeed, $n_{H_{2}}^{\text {loss }}$ depends on anode pressure, temperature, purge interval, the condition of channel flooding and the amount of nitrogen blanketing [9]. Furthermore, Chen et al. [9] show, through modelling, that distinct regions of a dominant gas composition form in particular localities within the anode channels during operation: a $\mathrm{H}_{2}$-rich region develops near the anode inlet with the same composition as the inlet fuel mix, and a $100 \% \mathrm{~N}_{2}$ blanket region accumulates towards the anode outlet, and that the boundary of these regions is in dynamic response to the time point in the purge cycle. For the purposes of this study, therefore, a simplified version of the Chen et al. model was employed whereby only two regions were considered $\left(\mathrm{H}_{2}\right.$-rich and $\mathrm{N}_{2}$ blanket regions) and both water 
accumulation in the fuel stream and extensive dehydration in the centre of the stack [15] were neglected. For the purposes of this study this simplification is sensible.

The nitrogen accumulation in the anode, $n_{N_{2}}$, over a DEA cycle can be calculated as a function of the number of moles of $\mathrm{H}_{2}$ consumed, $y_{N_{2}}$ the molar fraction of nitrogen in the fuel mix, and $n_{N_{2}}^{\text {permeation }}$ the number of moles of nitrogen that permeated through the membrane from the cathode (Equation 4):

$n_{N_{2}}=n_{H_{2}}^{\text {consumed }} y_{N_{2}}+n_{N_{2}}^{\text {permeation }}$

According to the literature, the $\mathrm{N}_{2}$ accumulation rate at the anode via permeation from the air is $0.01-0.03 \% \mathrm{~s}^{-1}[33,34]$. However, in this study the $\mathrm{N}_{2}$ accumulation rate at the anode caused by the composition of the fuel itself is substantial (e.g. $21 \% \mathrm{~s}^{-1}$ at a current density of $0.25 \mathrm{~A} \mathrm{~cm}^{-2}$ for the $75 \mathrm{H}_{2}: 25 \mathrm{~N}_{2}$ gas mix). Consequently the $\mathrm{N}_{2}$ accumulation rate via permeation from air in the cathode is negligible and its contribution to Equation 3 can effectively be ignored.

The nitrogen blanketed volume, $V_{N_{2}}$, in the anode compartment can be estimated from the ideal gas law (Equation 5):

$V_{N_{2}}=\frac{n_{N_{2}} R T_{\text {cell }}}{\left(P_{\text {atm }}+P_{\text {anode }}\right)}$

where $T_{\text {cell }}$ is the cell temperature, $P_{a t m}$ the atmospheric pressure and $P_{\text {anode }}$ the average anode over-pressure during the DEA cycle. The time taken to purge the accumulated nitrogen, $t_{p, N_{2}}$, is then estimated from the volumetric purge flow rate, $\dot{V}_{\text {purge }}$ (Equation 6):

$t_{p, N_{2}}=\frac{V_{N_{2}}}{\dot{V}_{\text {purge }}}$

Combining all these components allows the number of moles of hydrogen lost, $n_{\mathrm{H}_{2}}^{\text {loss}}$, to be expressed as (Equation 7): 
$n_{H_{2}}^{\text {loss }}=\frac{\left(t_{p}-t_{p, N_{2}}\right) \dot{V}_{\text {purge }} y_{H_{2}}}{V_{m}}$

where $t_{p}$ is the purge interval, $y_{H_{2}}$ the molar fraction of hydrogen in the fuel mix and $V_{m}$ the molar volume of gas at STP $\left(0^{\circ} \mathrm{C}, 1 \mathrm{~atm}\right)$.

Meanwhile, the average power density, $W_{\text {average }}$, over $m$ cycles is given by Equation 8 :

$W_{\text {average }}=\frac{1}{t_{\text {tot }}} \int_{0}^{t_{\text {tot }}} V_{\text {mean cell }} j d t$

Having identified the components needed to calculate the stack efficiency (Equation 2) and the average power density (Equation 8), Table 1 summarises the physical constants used in these calculations. Given the $75 \mathrm{H}_{2}: 25 \mathrm{~N}_{2}$ fuel composition and DEA operating conditions, MATLAB® coding was used to process the resulting data during the DoE analysis.

Table 1. Parameters used to evaluate the stack efficiency and power density (at $0{ }^{\circ} \mathrm{C}$, 1 atm).

\begin{tabular}{|l|l|}
\hline Parameter & Value \\
\hline Molar volume of an ideal gas, $V_{m}$ & $22.4 \mathrm{~mol} \mathrm{l}^{-1}$ \\
\hline Electrode cross-section area, $A$ & $22.5 \mathrm{~cm}^{2}$ \\
\hline Faraday constant, $F$ & $96486 \mathrm{C} \mathrm{mol}^{-1}$ \\
\hline Flow rate during a purge, $\dot{V}_{\text {purge }}$ & $3.33 \times 10^{-6} \mathrm{~m}^{3} \mathrm{~s}^{-1}$ \\
\hline Enthalpy of formation of hydrogen, $\Delta h_{f}$ & $-242 \mathrm{~kJ} \mathrm{~mol}^{-1}$ \\
\hline Number of electrons of hydrogen exchanged, $n_{e}\left(H_{2}\right)$ & 2 \\
\hline Average anode over-pressure, $P_{\text {anode }}$ & $0.45 \mathrm{bar}$ \\
\hline Volume of the anodic compartment in a single cell, $V_{\text {anode }}$ & $10^{-6} \mathrm{~m}^{3}$ \\
\hline
\end{tabular}

\subsection{Impact of current density on stack performance}

The effect of varying the load on DEA operation using the $75 \mathrm{H}_{2}: 25 \mathrm{~N}_{2}$ fuel is examined in Fig. 5a. As before, a series of steady-state cyclical tests were used to determine the voltage degradation at particular current densities. These data show that as the load increases, the extent of voltage decay also increases (e.g. it takes $7 \mathrm{~s}$ to trigger the 
purge valve at $0.18 \mathrm{~A} \mathrm{~cm}^{-2}$ but only $2 \mathrm{~s}$ at $0.36 \mathrm{~A} \mathrm{~cm}^{-2}$ ). This observation can be reconciled by the fact that for every 3 moles of $\mathrm{H}_{2}$ consumed there is 1 mole of $\mathrm{N}_{2}$ that accumulates in the anode channel, coupled to the fact that Faraday's Law (Equation 3) states that $\mathrm{H}_{2}$ consumption increases with current density, thus $\mathrm{N}_{2}$ accumulation also increases in proportion to current density and leads to more rapid voltage losses.
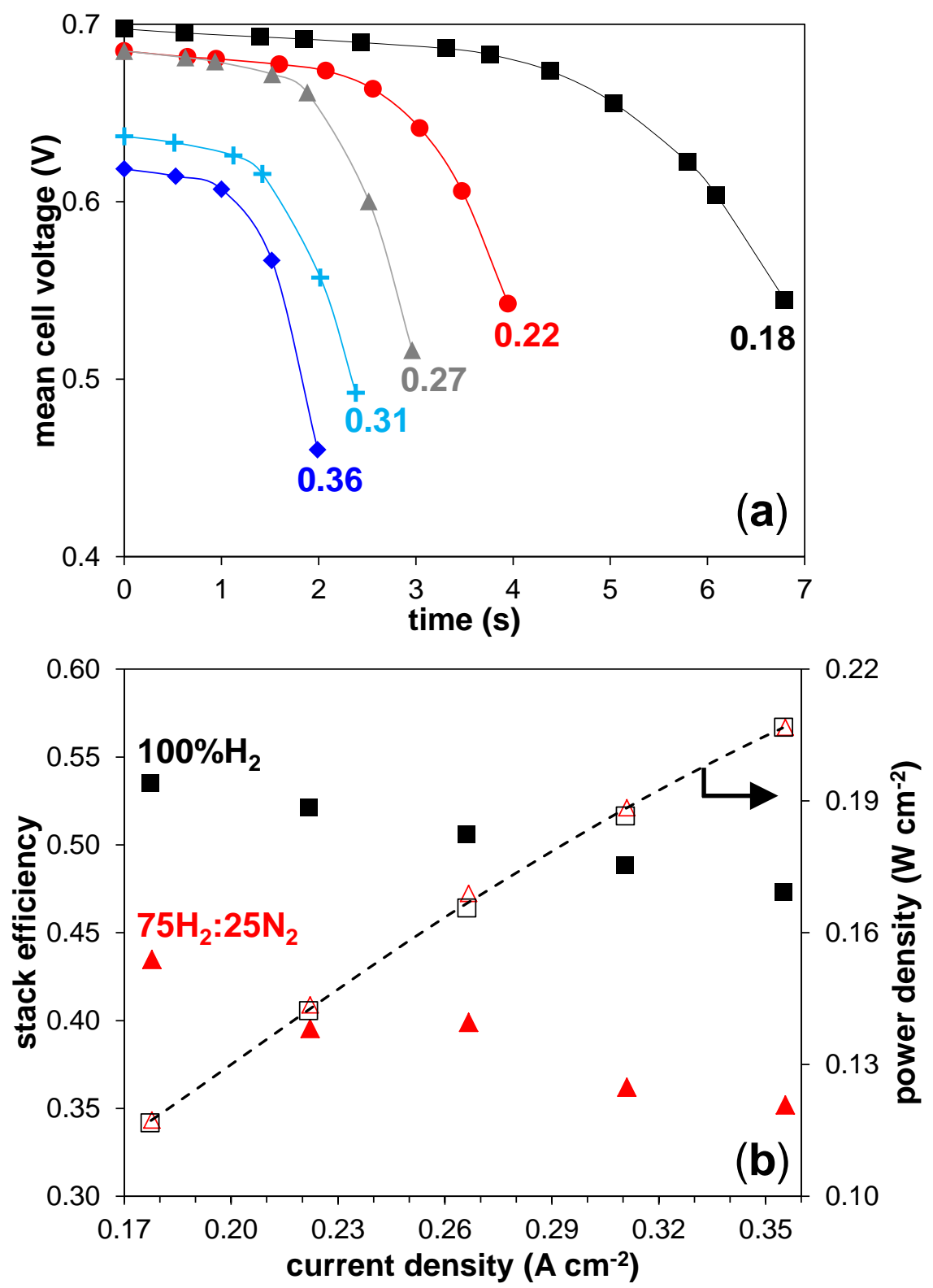

Fig. 5. Effect of varying the current density, between $0.18-0.36 \mathrm{~A} \mathrm{~cm}^{-2}$, on the fuel cell performance when operated in dead-ended mode with a $75 \mathrm{H}_{2}: 25 \mathrm{~N}_{2}$ gas supply: (a) mean cell voltage response versus time and (b) calculated stack efficiency (solid data points) and power density (open data points) responses (averaged over 10 cycles). The $100 \% \mathrm{H}_{2}$ responses are also shown in (b), as square data points. 
Fig. $5 \mathrm{~b}$ probes these interactions further, by comparing the calculated stack efficiencies and power densities for both $100 \% \mathrm{H}_{2}$ and $75 \mathrm{H}_{2}: 25 \mathrm{~N}_{2}$ across these current densities. It shows that when using the $75 \mathrm{H}_{2}: 25 \mathrm{~N}_{2}$ gas mix the averaged stack efficiency decreases by $19-26 \%$ compared to when operating with a $100 \% \mathrm{H}_{2}$ supply, irrespective of the operating load. The averaged power density, however, is unaffected by this increase in nitrogen content, since any voltage loss during a purge cycle is counter balanced by the initial increase in voltage at $t=0$ immediately after purging and a decrease in the purging cycle time. Thus although the averaged power density increases as the current density increases, the overall impact of the $75 \mathrm{H}_{2}: 25 \mathrm{~N}_{2}$ fuel mix is minimal (less than $1 \%$ ).

These results indicate that stack efficiency is a suitable parameter to use to assess DEA fuel cell performance, with DoE optimisation of this parameter an appropriate means of identifying the ideal operating conditions.

\subsection{Optimisation of the stack efficiency using Design of Experiment methodology}

In order to mitigate against voltage and fuel loses when using the $75 \mathrm{H}_{2}: 25 \mathrm{~N}_{2}$ gas mix, a DoE methodology was employed to identify a suitable purging strategy. Given that the current density also affects the stack efficiency (in terms of the non-linearity of the voltage decay process), the influence of purge interval, dead-ended interval and current density were selected as the variables of interest. An experimental plan with 2 levels $(-1)$ and $(+1)$ was considered for these three parameters, with stack efficiency used as the assessment (response) parameter (Table 2). The maximum and minimum values for the purge interval and dead-ended interval were identified based, respectively, on the time taken for the purge valve to open and then close and on the time taken for the cell voltage to drop below $0.50 \mathrm{~V}$. The current density values correspond to the bounded area of interest identified in the polarisation curve. 
Table 2. Design of Experiment (DoE) codes with their corresponding dead-ended anode fuel cell operation parameters.

\begin{tabular}{|l|l|l|l|}
\hline DoE code & description & $\begin{array}{l}\text { low value } \\
\text { “-1” }\end{array}$ & $\begin{array}{l}\text { high value } \\
\text { “+1" }\end{array}$ \\
\hline $\mathrm{X}_{1}$ & Purge interval (s) & 0.20 & $\mathbf{0 . 2 5}$ \\
\hline $\mathrm{X}_{2}$ & Dead-ended interval $(\mathrm{s})$ & 1.0 & 1.6 \\
\hline $\mathrm{X}_{3}$ & Current density $\left(\mathrm{A} \mathrm{cm}^{-2}\right)$ & 0.18 & 0.36 \\
\hline $\mathrm{Y}_{1}$ & Stack efficiency $(\eta)$ & - & - \\
\hline
\end{tabular}

For the experimental plan the purge interval, dead-ended interval and current density are coded $X_{1}, X_{2}$, and $X_{3}$, respectively. This gives three factors at two levels; therefore, $2^{3}$ runs were undertaken for the factorial study. A standard orthogonal array [35] was created, which allows for assessment of secondary interactions which can occur when the effect of one factor depends on the level of another factor (Table 3). The stack efficiency response $\left(Y_{1}\right)$ was calculated over 10 repeatable dead-ended cycles.

Table 3. Full factorial plans for three factors with secondary interactions showing eight experiments, plus three repeats at the centre of the domain. The maximum and minimum stack efficiency $\left(Y_{1}\right)$ responses are highlighted in bold.

\begin{tabular}{|l|l|l|l|l|l|l|l|l|l|}
\hline \multicolumn{2}{|c|}{} & \multicolumn{3}{l}{ Effect } & \multicolumn{4}{l|}{ Secondary interactions } & Response \\
\hline \multirow{4}{*}{ Runs } & $\mathrm{X}_{1}$ & $\mathrm{X}_{2}$ & $\mathrm{X}_{3}$ & $\mathrm{X}_{1} \mathrm{X}_{2}$ & $\mathrm{X}_{1} \mathrm{X}_{3}$ & $\mathrm{X}_{2} \mathrm{X}_{3}$ & $\mathrm{X}_{1} \mathrm{X}_{2} \mathrm{X}_{3}$ & $\mathrm{Y}_{1}$ \\
\hline \multirow{5}{*}{$\begin{array}{l}\text { Factorial } \\
\text { plan }\end{array}$} & 1 & -1 & -1 & -1 & +1 & +1 & +1 & -1 & 0.3107 \\
\cline { 2 - 10 } & 2 & +1 & -1 & -1 & -1 & -1 & +1 & +1 & 0.2807 \\
\cline { 2 - 10 } & 3 & -1 & +1 & -1 & -1 & +1 & -1 & +1 & 0.3824 \\
\cline { 2 - 10 } & 4 & +1 & +1 & -1 & +1 & -1 & -1 & -1 & 0.3475 \\
\cline { 2 - 10 } & 5 & -1 & -1 & +1 & +1 & -1 & -1 & +1 & 0.3852 \\
\cline { 2 - 9 } & 6 & +1 & -1 & +1 & -1 & +1 & -1 & -1 & 0.3610 \\
\cline { 2 - 9 } & 7 & -1 & +1 & +1 & -1 & -1 & +1 & -1 & 0.4265 \\
\cline { 2 - 9 } & 8 & +1 & +1 & +1 & +1 & +1 & +1 & +1 & 0.4051 \\
\hline \multirow{4}{*}{ Repeats } & 9 & 0 & 0 & 0 & 0 & 0 & 0 & 0 & 0.3805 \\
\cline { 2 - 9 } & 10 & 0 & 0 & 0 & 0 & 0 & 0 & 0 & 0.3794 \\
\cline { 2 - 9 } & 11 & 0 & 0 & 0 & 0 & 0 & 0 & 0 & 0.3816 \\
\hline
\end{tabular}

Analysing these responses shows that the highest stack efficiency was obtained for the lowest purge interval, yet highest purge duration and current density (Run 7, 
$Y_{1}=0.4265$ ), and the lowest stack efficiency was obtained for the highest purge interval, lowest dead-ended interval and current density (Run 2, $Y_{1}=0.2807$ ) conditions. This provides an initial indication as to what weighting should be applied to each parameter.

Additionally, three repeat runs were undertaken (Runs 9, 10 \& 11 in Table 3) which correspond to three batches of experiments at the centre of the domain (hence the assignment of ' 0 ' in the Table 3). These data were used to validate the model since these experimental conditions were not used in the original coefficient calculation process. They also verify that the measurements are reproducible and possess a low standard deviation $(\sigma=0.00895)$. As the standard deviation is significantly below the mean response $\left(Y_{1}=0.3805\right)$, it is possible to build multi-linear models to study the effect of the different factors upon the response. AVL CAMEO ${ }^{\text {TM }}$ software $(2014, \mathrm{v} 3.7)$ was used to calculate these coefficients, and generate the surface response plot. Adding quadratic effects using the three repeats enhances the accuracy of the prediction in the centre of the domain. Only coefficients greater than the experimental error $\left(\frac{\sigma}{\sqrt{3}}\right)$ were considered, such that a stack efficiency empirical equation could be determined (Equation 9). The standardised model coefficients (i.e. the coefficient weightings normalised during the stack efficiency modelling calculation) are shown graphically in Fig. 6.

$Y_{1}\left(X_{1}, X_{2}, X_{3}\right)=0.3805-0.012 X_{1}+0.025 X_{2}-0.028 X_{3}+0.0019 X_{1} X_{3}-0.0053 X_{2} X_{3}-0.014 X_{2}^{2}$ 


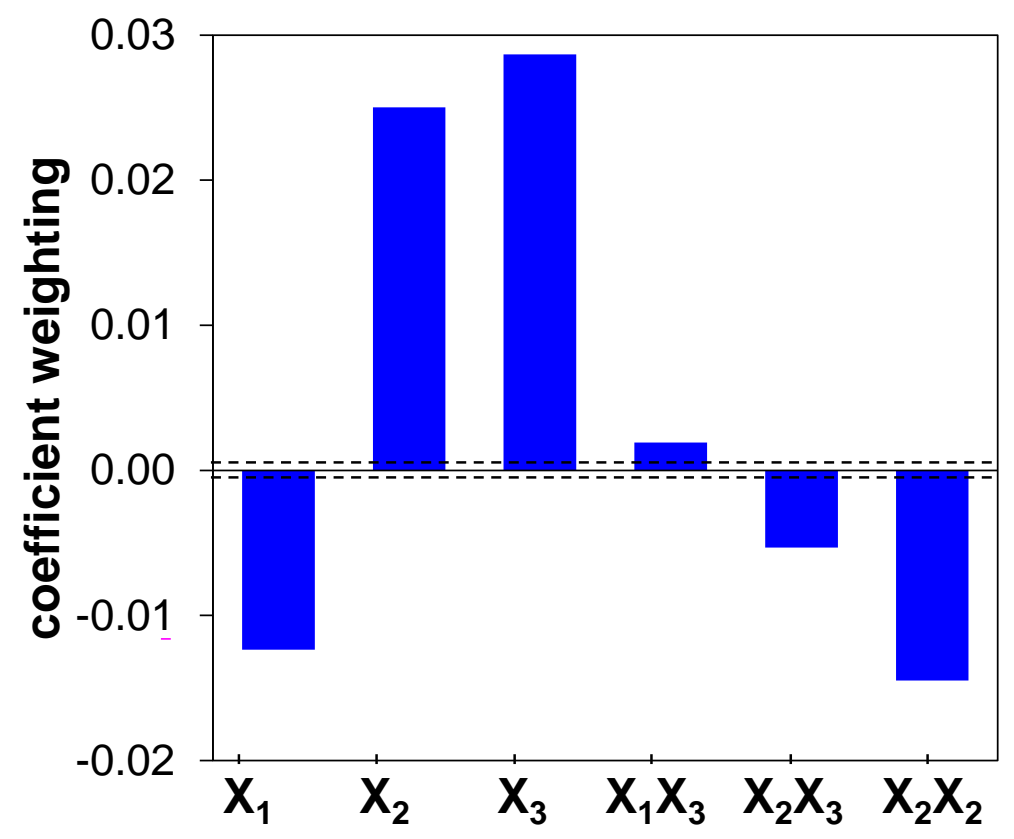

Fig. 6. Contribution of the DoE parameters, and their interactions, on the stack efficiency. The dotted lines at \pm 0.00052 indicate the experimental error $(\sigma / \sqrt{ } 3)$.

The weight of the primary coefficients shows that increasing the purge interval reduces the stack efficiency, whereas increasing the current density and dead-ended interval increases the stack efficiency. However, the secondary terms show that although a combination of increasing the current density and purge duration will slightly increase the stack efficiency, the equivalent combination of increasing the current density and the dead-ended time will decrease it. Overall the current density has the greatest effect; however, the influence of the other parameters cannot be ignored entirely.

The AVL CAMEO ${ }^{\mathrm{TM}}$ modelling software identified a maximum, based upon the findings of Equation 9, which corresponds to an optimum constant current density of $0.36 \mathrm{~A} \mathrm{~cm}^{-2}\left(X_{3}=+1\right)$. This surface response plot is shown in Fig. 7. A close examination of this surface shows that the maximum stack efficiency $(\eta=0.4305)$ is predicted to be achieved for a dead-ended interval of $1.47 \mathrm{~s}$ and a purge interval of $0.20 \mathrm{~s}$. This improvement, predicted by the DoE methodology, is close to the stack efficiency obtained when using $100 \% \mathrm{H}_{2}$ and indicates that the operation of a PEFC using a $75 \mathrm{H}_{2}: 25 \mathrm{~N}_{2}$ gas feed is viable (Table 4). 


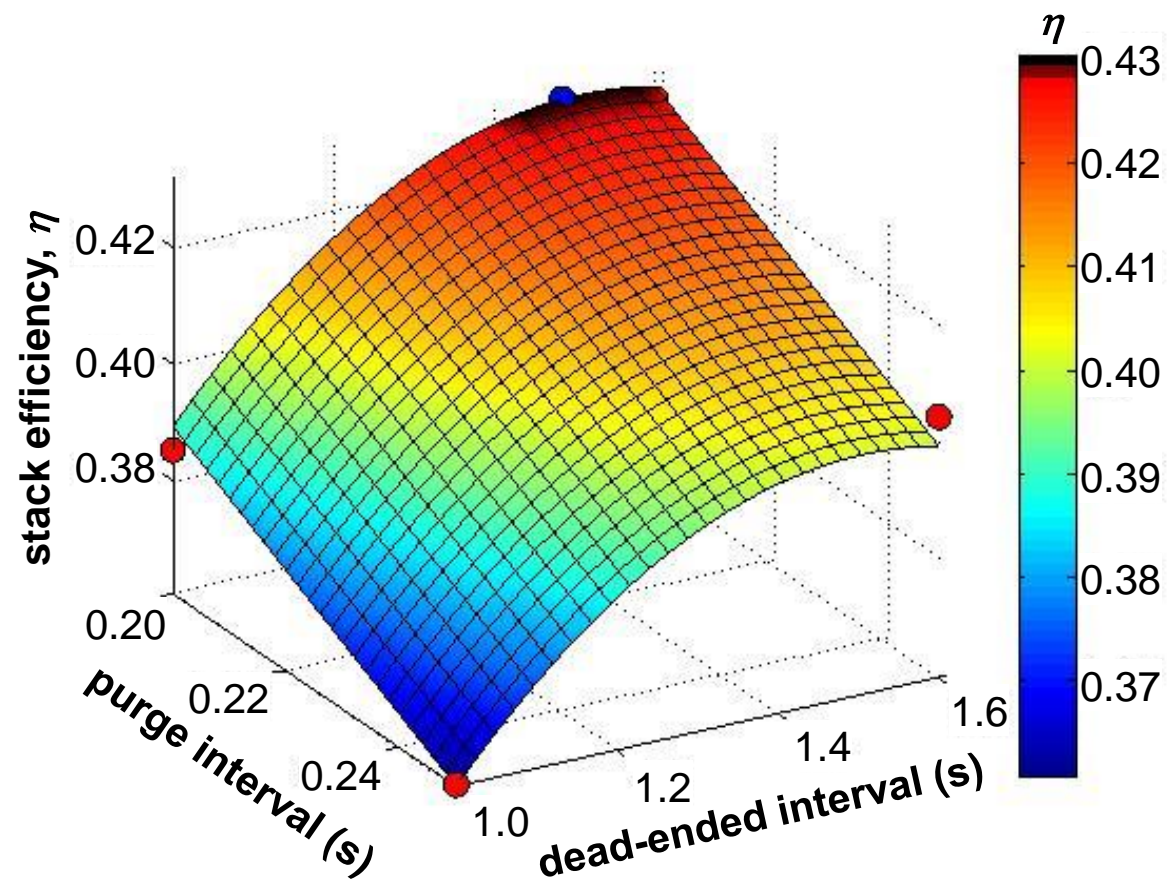

Fig. 7. Surface response chart showing the experimentally measured (red) and the predicted maximum (blue) data points, for the fuel cell stack efficiency obtained from a $75 \mathrm{H}_{2}: 25 \mathrm{~N}_{2}$ gas supply at $0.36 \mathrm{~A} \mathrm{~cm}^{-2}$.

Table 4. Summary of the fuel cell stack efficiency when operated at $0.36 \mathrm{~A} \mathrm{~cm}^{-2}$ under various feed gas conditions.

\begin{tabular}{|l|l|l|l|l|}
\hline \multirow{2}{|l|}{ Feed gas composition } & $\begin{array}{l}\text { Stack } \\
\text { Efficiency }\end{array}$ & $\begin{array}{l}\text { Purge } \\
\text { interval / s }\end{array}$ & $\begin{array}{l}\text { Dead-ended } \\
\text { interval / s }\end{array}$ \\
\hline $100 \% \mathrm{H}_{2}$ & 0.4730 & 1.0 & 600 \\
\hline \multirow{2}{*}{$75 \mathrm{H}_{2}: 25 \mathrm{~N}_{2}$} & Before optimisation & 0.3519 & $\sim 0.50$ & $\sim 2$ \\
\cline { 2 - 5 } & After optimisation & 0.4305 & 0.20 & 1.47 \\
\hline
\end{tabular}

Further investigations are planned, with a particular focus to accurately match the purge interval with the time taken to purge the accumulated nitrogen, $t_{p, N_{2}}$, in order to minimise $\mathrm{H}_{2}$ fuel losses. At present, $t_{p, N_{2}}$ is estimated (Equation 6) at $0.0453 \mathrm{~s}$ and $0.115 \mathrm{~s}$ for Runs 1 and 8 , respectively, yet the minimum purge interval allowed during this full factorial plan was $0.20 \mathrm{~s}$. Combined, these results suggest that fuel losses could be further avoided; however, an upgrade to the communication speed between the data logging hardware and computer controlled software is necessary in order to investigate this effectively. Also under consideration is the long term durability of the 
fuel cell stack, when exposed to the nitrogen-containing hydrogen feed gas, and the impact, if any, this may have upon water management in the fuel cell.

\section{Summary}

This study examines the effect of nitrogen content within the hydrogen fuel supplied to a polymer electrolyte fuel cell operating in dead-ended anode mode, with a view to using an ammonia decomposition product gas mix (containing $75 \mathrm{H}_{2}: 25 \mathrm{~N}_{2}$ ) as the hydrogen-containing fuel. The impact of this impure hydrogen stream is assessed in terms of mean cell voltage and in relation to actual operating conditions (purge interval, dead-ended interval and fuel cell load). As the nitrogen content in the fuel supplied to the $\mathrm{H}-100$ fuel cell anode increases, the rate of voltage degradation increases, indicating that voltage loss is correlated to $\mathrm{N}_{2}$ accumulation in the anode channels. This effect is extended when the current density increases. Design of Experiments methodology, using multi-linear models, is effective at assessing the role of the primary operating parameters (purge interval, dead-ended interval and current density) and identifying if any secondary or quadratic effects exist. The resultant surface response plot shows that stack efficiency is heavily influenced by the current density, and identifies the conditions for a viable purge strategy for use with the ammonia decomposition product gas mix. Consequently, this PEFC purge strategy extends the potential for the ammonia molecule as a hydrogen storage vector in the alternative energy marketplace, bringing its use in environmentally sustainable portable, transport and off-grid power generation applications one step closer.

\section{Acknowledgements}

The authors acknowledge the technical assistance of Mark Kibble, Jamie Nutter and John Crawford at STFC, and also thank Bill David, Beth Evans and Liam Brennan for useful guidance. We thank Simon Barrass and Jason Millichamp, from the Department of Chemical Engineering at UCL, for their help in setting up the experiments. We are grateful to Simon Mylius (Arcola Energy Ltd) for his technical input and to AVL.com for provision of the surface modelling software. This work was financially supported by an 
STFC CLASP award (ST/L006278/1), an STFC Innovations Proof-of-Concept award (POCF1516-04) and three EPSRC grants (EP/M009394/1, EP/M023508/1 and EP/M014371/1). PRS acknowledges funding from the Royal Academy of Engineering.

\section{References}

[1] Huang Z, Autrey T. Boron-nitrogen-hydrogen (BNH) compounds: recent developments in hydrogen storage, applications in hydrogenation and catalysis, and new syntheses. Energy Environ. Sci., 2012; 5, 9257-9268. doi:10.1039/c2ee23039a. [2] Li HW, Yan Y, Orimo SI, Züttel A, Jensen CM. Recent progress in metal borohydrides for hydrogen storage. Energies, 2011, 4, 185-214. doi:10.3390/en4010185.

[3] David WIF,Makepeace JW, Callear SK, Hunter HMA, Taylor JD, Wood TJ, Jones MO. Hydrogen production from ammonia using sodium amide. J. Am. Chem. Soc., 2014, 136, 13082-130855. doi:10.1021/ja5042836.

[4] Makepeace JW, Wood TJ, Hunter HMA, Jones MO, David WIF. Ammonia decomposition catalysis using non-stoichiometric lithium imide. Chem. Sci., 2015, 6, 3805-3815. doi:10.1039/c5sc00205b.

[5] Wood TJ, Makepeace JW, Hunter HMA, Jones MO, David WIF. Isotopic studies of the ammonia decomposition reaction mediated by sodium amide. Phys. Chem. Chem. Phys., 2015, 17, 22999-23006. doi:10.1039/c5cp03560k.

[6] Hunter HMA, Makepeace JW, Wood TJ, Mylius OS, Kibble MG, Nutter JB, Jones MO, David WIF, Demonstrating hydrogen production from ammonia with an imide catalyst - powering a small proton exchange membrane fuel cell. J. Power Sources, 2016, submitted.

[7] Ichikawa Y, Oshimi N, Tabuchi Y, Ikezoe K. Transient analysis of gas transport in anode channel of a polymer electrolyte membrane fuel cell with dead-ended anode under pressure swing operation. J. Power Sources, 2014, 272, 743-752. doi.org/10.1016/j.jpowsour.2014.09.023.

[8] Siegel JB, Bohac SV., Stefanopoulou AG, Yesilyurt S. Nitrogen front evolution in purged polymer electrolyte membrane fuel cell with dead-ended anode. J. Electrochem. Soc., 2010, 157, B1081-B1093. doi:10.1149/1.3425743. 
[9] Chen J, Siegel JB, Stefanopoulou AG, Waldecker JR. Optimization of purge cycle for dead-ended anode fuel cell operation. Int. J. Hydrogen Energy, 2013, 38, 5092-5105. doi:10.1016/j.ijhydene.2013.02.022.

[10] Yesilyurt S, Siegel JB, Stefanopoulou AG. Modeling and experiments of voltage transients of polymer electrolyte membrane fuel cells with the dead-ended anode. J. Fuel Cell Sci. Technol., 2012, 9(2), 021012. doi:10.1115/1.4005626.

[11] Sasmito AP, Mujumdar AS. Performance evaluation of a polymer electrolyte fuel cell with a dead-ended anode: a computational fluid dynamic study. Int. J. Hydrogen Energy, 2011, 36, 10917-10933. doi:10.1016/j.ijhydene.2011.05.171. [12] Hou Y, Shen C, Yang Z, He Y. A dynamic voltage model of a fuel cell stack considering the effects of hydrogen purge operation. Renewable Energy, 2012, 44, 246-251. doi:10.1016/j.renene.2012.01.088.

[13] Baik KD, Kim MS. Characterization of nitrogen gas crossover through the membrane in proton-exchange membrane fuel cells. Int. J. Hydrogen Energy, 2011, 36, 732-739. doi:10.1016/j.jijhydene.2010.09.046.

[14] Rabbani A, Rokni M. Effect of nitrogen crossover on purging strategy in PEM fuel cell systems. Applied Energy, 2013, 111, 1061-1070. doi:10.1016/j.apenergy.2013.06.057.

[15] Meyer Q, Ashton S, Torija S, Gurney C, Boillat P, Cochet M, Engebretsen E, Finegan DP, Adcock P, Shearing PR, Brett DJL. Nitrogen blanketing and hydrogen starvation in dead-ended-anode polymer electrolyte fuel cells revealed by hydroelectro-thermal analysis. Electrochim. Acta, 2016, 203, 198-205. doi:10.1016/j.electacta.2016.04.018.

[16] Siegel JB, McKay DA, Stefanopoulou AG, Hussey DS, Jacobson DL. Measurement of liquid water accumulation in a PEMFC with dead-ended anode. J. Electrochem. Soc., 2008, 155, B1168-B1178. doi:10.1149/1.2976356.

[17] Stahl P, Biesdorf J, Boillat $P$, Kraft J, Friedrich KA. Water distribution analysis in the outer perimeter region of technical PEFC based on neutron radiography. J. Electrochem. Soc., 2015, 162(7), F677-F685. doi:10.1149/2.0351507jes. [18] Lee Y, Kim B, Kim Y. An experimental study on water transport through the membrane of a PEFC operating in the dead-end mode. Int. J. Hydrogen Energy 2009, 34, 7768-7779. doi:10.1016/j.ijhydene.2009.07.010. 
[19] Nachiappan N, Paruthimal Kalaignan G, Sasikumar G. Effect of nitrogen and carbon dioxide as fuel impurities on PEM fuel cell performances. Ionics, 2013, 19, 351-354. doi:10.1007/s11581-012-0730-z.

[20] Um S, Wang C-Y, Chen KS. Computational fluid dynamics modeling of proton exchange membrane fuel cells, J. Electrochem. Soc., 2000, 147(12), 4485-4493. doi:10.1149/1.1394090.

[21] Yu J, Jiang Z, Hou M, Liang D, Xiao Y, Dou M, Shao Z, Yi B. Analysis of the behavior and degradation in proton exchange membrane fuel cells with a deadended anode. J. Power Sources, 2014, 246, 90-94.

doi:10.1016/j.jpowsour.2013.06.163.

[22] Wahdame B, Candusso D, François X, Harel F, Kauffmann J, Coquery G.

Design of experiment techniques for fuel cell characterisation and development. Int. J. Hydrogen Energy, 2009, 34, 967-980. doi:10.1016/j.ijhydene.2008.10.066. [23] Telford JK. A brief introduction to design of experiments. Johns Hopkins APL Technical Digest, 2007, 27, 224-232.

[24] Sleem-ur-Rahman, Al-Saleh MA, Al-Zakri AS. Parametric study of the preparation of gas-diffusion electrodes for alkaline fuel cells by a filtration method. J. Power Sources, 1998, 72, 71-76. doi:10.1016/S0378-7753(97)02672-4.

[25] Grujicic M, Chittajallu KM. Optimization of the cathode geometry in polymer electrolyte membrane (PEM) fuel cells. Chem. Eng. Sci., 2004, 59, 5883-5895. doi:10.1016/j.ces.2004.07.045.

[26] Rama P, Chen R, Andrews J. A review of performance degradation and failure modes for hydrogen-fuelled polymer electrolyte fuel cells. Proc. Institution Mech.

Eng. Part A: J. Power Energy, 2008, 222(5), 421-441. doi:10.1243/09576509JPE603.

[27] Akyalçın L, Kaytakoğlu S. Optimization of structural combinations on the performance of a PEMFC's MEA. J. Power Sources, 2008,180(2), 767-772. doi:10.1016/j.jpowsour.2008.02.036.

[28] Endoo S, Pruksathorn K, Piumsomboon P. Identification of the key variables in membrane electrode preparation for PEM fuel cells by a factorial design. Renewable Energy, 2010, 35, 807-813. doi:10.1016/j.renene.2009.10.013.

[29] Wahdame B, Candusso D, François X, Harel F, De Bernardinis A, Kauffmann J-M, Coquery G, Study of a $5 \mathrm{~kW}$ PEMFC using experimental design and statistical analysis techniques. Fuel Cells, 2007, 7(1), 47-62. doi:10.1002/fuce.200500256. 
[30] Chang K-Y, Lin H-J, Chen P-C. The optimal performance estimation for an unknown PEMFC based on the Taguchi method and a generic numerical PEMFC model. Int. J. Hydrogen Energy, 2009, 34, 1990-1998.

doi:10.1016/j.jhydene.2008.11.100.

[31] Torchio MF, Santarelli MG, Nicali A. Experimental analysis of the CHP performance of a PEMFC stack by a $2^{4}$ factorial design. J. Power Sources, 2005, 149, 33-43. doi:10.1016/j.jpowsour.2005.01.060.

[32] Meyer Q, Ronaszegi K, Robinson JB, Noorkami M, Curnick O, Ashton S, Danelyan A, Reisch T, Adcock P, Kraume R, Shearing PR, Brett DJL. Combined current and temperature mapping in an air-cooled, open-cathode polymer electrolyte fuel cell under steady-state and dynamic conditions. J. Power Sources, 2015, 297, 315-322. doi:10.1016/j.jpowsour.2015.07.069.

[33] Meyer Q, Ashton S, Curnick O, Reisch T, Adcock P, Ronaszegi K, Robinson JB, Brett DJL. Dead-ended anode polymer electrolyte fuel cell stack operation investigated using electrochemical impedance spectroscopy, off-gas analysis and thermal imaging. J. Power Sources, 2014, 254, 1-9.

doi:10.1016/j.jpowsour.2013.11.125.

[34] Müller EA, Kolb F, Guzzella L, Stefanopoulou AG, McKay DA. Correlating nitrogen accumulation with temporal fuel cell performance. J. Fuel Cell Sci. Technol., 2010, 7, 021013. doi:10.1115/1.3177447.

[35] Anderson MJ, Whitcomb PJ. "Two-level factorial design" in: DOE Simplified: practical tools for effective experimentation. 3rd ed., 2015, CRC Press, Boca Raton, Florida, USA, Ch. 3, 37-67. 
Supplementary Information for:

Development of a Polymer Electrolyte Fuel Cell Dead-Ended Anode Purge Strategy for use with a Nitrogen-containing Hydrogen Gas Supply

Tonny I. Okedi ${ }^{1}$, Quentin Meyer ${ }^{1}$, Hazel M.A. Hunter ${ }^{2 \star}$, Paul R. Shearing ${ }^{1}$, Dan J.L. Brett ${ }^{*}$

${ }^{1}$ Electrochemical Innovation Lab, Department of Chemical Engineering, UCL, London, WC1E 7JE, UK.

${ }^{2}$ ISIS Facility, STFC Rutherford Appleton Laboratory, Harwell Campus, Didcot, Oxfordshire, OX11 0QX, UK.

Corresponding authors: hazel.hunter@stfc.ac.uk and d.brett@ucl.ac.uk

\begin{tabular}{lc}
\hline Contents: & Page \\
\hline Section A - Process \& Instrumentation Diagram & S2 \\
Section B - Raw data for Figures & S4 \\
\hline
\end{tabular}


Section A - Process and Instrumentation Diagram

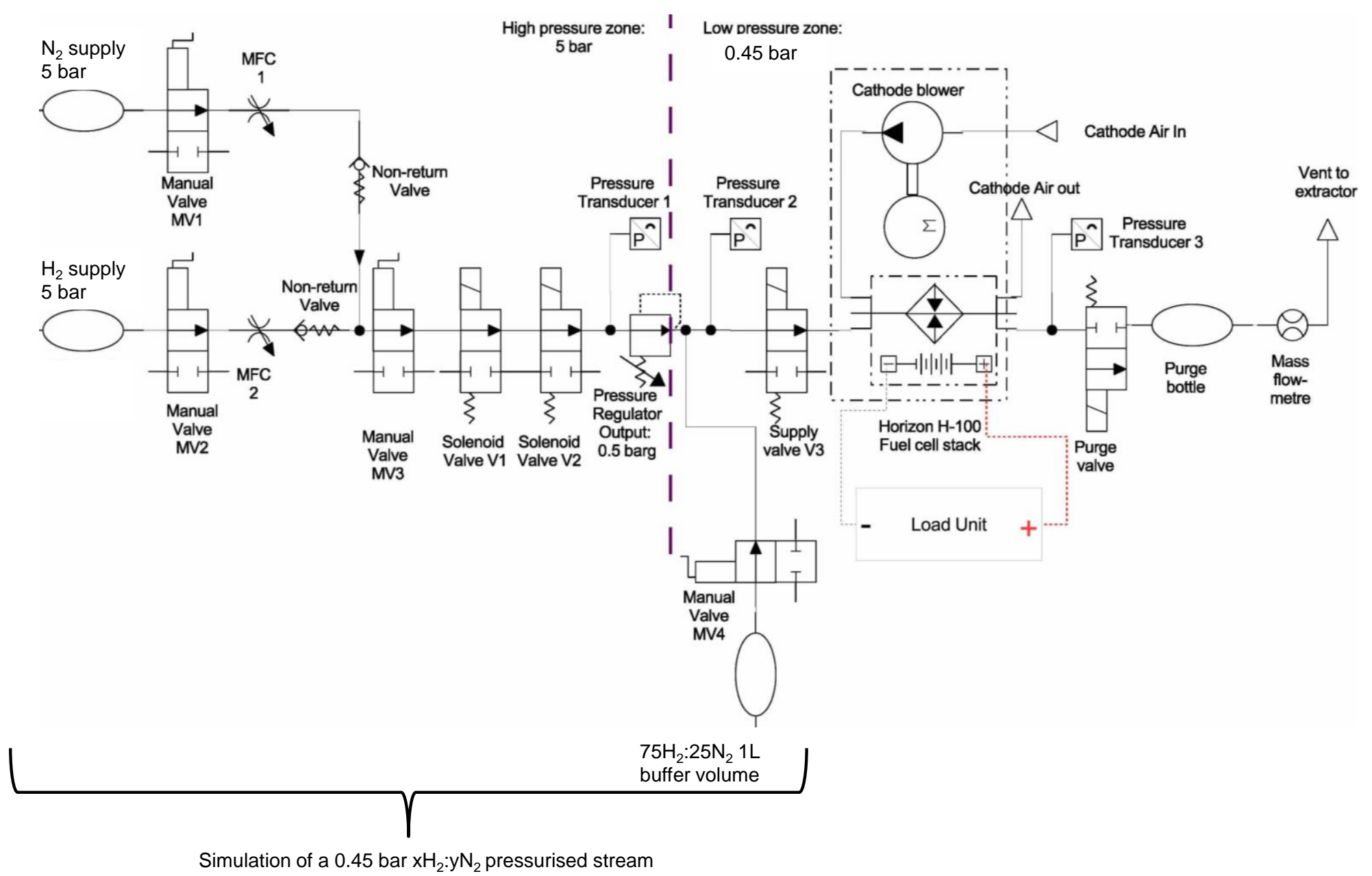

Figure S1: Process and Instrumentation Diagram of the experimental set-up. 
Section B - Raw data for Figures

Table S1: $\mathrm{H}-100$ polarisation curve raw data for Figure 3a.

\begin{tabular}{|c|c|c|}
\hline Current density $\left(\mathrm{A} \mathrm{cm}^{-2}\right)$ & Mean cell voltage $(\mathrm{V})$ & power density $\left(\mathrm{W} \mathrm{cm}^{-2}\right)$ \\
\hline 0 & 0.95145 & 0 \\
\hline 0.01075 & 0.76986 & 0.00827 \\
\hline 0.02188 & 0.73693 & 0.01613 \\
\hline 0.03326 & 0.71395 & 0.02374 \\
\hline 0.044 & 0.70279 & 0.03092 \\
\hline 0.05511 & 0.69629 & 0.03837 \\
\hline 0.06622 & 0.69208 & 0.04583 \\
\hline 0.07733 & 0.68669 & 0.0531 \\
\hline 0.08844 & 0.68628 & 0.0607 \\
\hline 0.09957 & 0.68357 & 0.06806 \\
\hline 0.11067 & 0.68118 & 0.07538 \\
\hline 0.12178 & 0.67901 & 0.08269 \\
\hline 0.13333 & 0.6741 & 0.08988 \\
\hline 0.144 & 0.66991 & 0.09647 \\
\hline 0.15511 & 0.66601 & 0.1033 \\
\hline 0.16653 & 0.66158 & 0.11017 \\
\hline 0.17733 & 0.65809 & 0.1167 \\
\hline 0.18844 & 0.65276 & 0.12301 \\
\hline 0.19956 & 0.64943 & 0.1296 \\
\hline 0.21067 & 0.64513 & 0.13591 \\
\hline 0.22179 & 0.64116 & 0.1422 \\
\hline 0.23292 & 0.63644 & 0.14824 \\
\hline 0.24419 & 0.63092 & 0.15407 \\
\hline 0.25511 & 0.6268 & 0.1599 \\
\hline 0.26622 & 0.62202 & 0.16559 \\
\hline 0.27733 & 0.61673 & 0.17104 \\
\hline 0.28844 & 0.61141 & 0.17636 \\
\hline 0.29956 & 0.60613 & 0.18157 \\
\hline 0.31069 & 0.60045 & 0.18656 \\
\hline 0.32178 & 0.59584 & 0.19173 \\
\hline 0.33289 & 0.59294 & 0.19738 \\
\hline 0.344 & 0.58718 & 0.20199 \\
\hline 0.35511 & 0.58222 & 0.20675 \\
\hline 0.36622 & 0.57672 & 0.21121 \\
\hline 0.37733 & 0.57116 & 0.21552 \\
\hline 0.38844 & 0.56572 & 0.21975 \\
\hline 0.39956 & 0.55966 & 0.22361 \\
\hline 0.41068 & 0.55333 & 0.22724 \\
\hline 0.42178 & 0.54707 & 0.23074 \\
\hline 0.43289 & 0.53989 & 0.23371 \\
\hline
\end{tabular}

Table continues... 


\begin{tabular}{|c|c|c|}
\hline Current density $\left(\mathrm{A} \mathrm{cm}^{-2}\right)$ & Mean cell voltage $(\mathrm{V})$ & power density $\left(\mathrm{W} \mathrm{cm}^{-2}\right)$ \\
\hline 0.444 & 0.53291 & 0.23661 \\
\hline 0.45511 & 0.53084 & 0.24159 \\
\hline 0.46622 & 0.52871 & 0.2465 \\
\hline 0.47733 & 0.5223 & 0.24931 \\
\hline 0.48852 & 0.51599 & 0.25207 \\
\hline 0.51067 & 0.50266 & 0.25669 \\
\hline 0.53111 & 0.48622 & 0.25824 \\
\hline 0.544 & 0.47801 & 0.26004 \\
\hline 0.55511 & 0.46851 & 0.26008 \\
\hline 0.56622 & 0.4552 & 0.25775 \\
\hline 0.52178 & 0.49549 & 0.25854 \\
\hline 0.49956 & 0.50961 & 0.25458 \\
\hline
\end{tabular}


Table S2: Voltage decay raw data for Figure 3b, where $X$ values are time (s) and $Y$ values are mean cell voltage (V).

\begin{tabular}{|c|c|c|c|c|c|c|c|c|c|c|c|}
\hline $\mathrm{X} 1$ & Y1 & $\mathrm{X} 2$ & Y2 & $\mathrm{X} 3$ & Y3 & $X 4$ & Y4 & $\times 5$ & Y5 & $\times 6$ & Y6 \\
\hline $100 \% \mathrm{H}_{2}$ & $100 \% \mathrm{H}_{2}$ & $95 \mathrm{H}_{2}: 5 \mathrm{~N}_{2}$ & $95 \mathrm{H}_{2}: 5 \mathrm{~N}_{2}$ & $90 \mathrm{H}_{2}: 10 \mathrm{~N}_{2}$ & $90 \mathrm{H}_{2}: 10 \mathrm{~N}_{2}$ & $85 \mathrm{H}_{2}: 15 \mathrm{~N}_{2}$ & $85 \mathrm{H}_{2}: 15 \mathrm{~N}_{2}$ & $80 \mathrm{H}_{2}: 20 \mathrm{~N}_{2}$ & $80 \mathrm{H}_{2}: 20 \mathrm{~N}_{2}$ & $75 \mathrm{H}_{2}: 25 \mathrm{~N}_{2}$ & $75 \mathrm{H}_{2}: 25 \mathrm{~N}_{2}$ \\
\hline 0 & 0.60081 & 0 & 0.66122 & 0 & 0.65635 & 0 & 0.6608 & 0 & 0.66408 & 0 & 0.66041 \\
\hline 0.625 & 0.60068 & 0.43002 & 0.65771 & 0.36002 & 0.65729 & 0.60103 & 0.65501 & 0.44 & 0.65948 & 0.218 & 0.64622 \\
\hline 0.91803 & 0.60083 & 0.87105 & 0.65595 & 0.57403 & 0.65613 & 0.81905 & 0.65221 & 0.87103 & 0.64889 & 0.45001 & 0.61277 \\
\hline 1.51709 & 0.60087 & 1.07106 & 0.65524 & 0.76404 & 0.65514 & 1.01405 & 0.64867 & 1.08203 & 0.63567 & 0.85605 & 0.35 \\
\hline 2.0061 & 0.60071 & 1.49408 & 0.6529 & 1.15707 & 0.65171 & 1.41308 & 0.62922 & 1.50305 & 0.45364 & & \\
\hline 2.47711 & 0.60089 & 2.12611 & 0.64812 & 1.57509 & 0.64491 & 1.60709 & 0.61215 & & & & \\
\hline 2.93115 & 0.60073 & 2.36713 & 0.64554 & 1.7681 & 0.64076 & 1.8331 & 0.58315 & & & & \\
\hline 3.3692 & 0.60063 & 2.99817 & 0.6352 & 2.14212 & 0.62557 & 2.24612 & 0.51773 & & & & \\
\hline 4.18219 & 0.60084 & 3.4372 & 0.63026 & 2.72716 & 0.59625 & & & & & & \\
\hline 4.48926 & 0.60067 & 3.87022 & 0.62623 & 3.11217 & 0.55195 & & & & & & \\
\hline 5.18726 & 0.60075 & 4.29224 & 0.62181 & 3.4792 & 0.49195 & & & & & & \\
\hline 5.49732 & 0.60073 & 4.93527 & 0.61041 & & & & & & & & \\
\hline 6.0813 & 0.60099 & 5.3743 & 0.59933 & & & & & & & & \\
\hline 6.37433 & 0.60083 & 5.78133 & 0.58304 & & & & & & & & \\
\hline \multirow[t]{2}{*}{7.0354} & 0.60071 & 6.20836 & 0.55527 & & & & & & & & \\
\hline & & 6.81239 & 0.49901 & & & & & & & & \\
\hline
\end{tabular}


Table S3: Mean voltage across 10 cycles raw data for Figure 4b.

\begin{tabular}{|c|c|c|c|c|c|}
\hline \multicolumn{3}{|c|}{ with buffer } & \multicolumn{3}{c|}{ without buffer } \\
\hline $\mathbf{X 1}$ & Y1 & Yerr+/- & X2 & Y2 & Yerr+/- \\
\hline 0 & 0.68097 & 0.00332 & 0 & 0.6647 & 0.0533 \\
\hline 0.92804 & 0.67927 & 0.00102 & 0.42702 & 0.6652 & 0.04362 \\
\hline 1.52008 & 0.67254 & 0.00319 & 1.07106 & 0.6466 & 0.05652 \\
\hline 2.00009 & 0.65245 & 0.01054 & 1.51808 & 0.60222 & 0.04043 \\
\hline 2.43912 & 0.61363 & 0.02336 & 2.14612 & 0.55609 & 0.07027 \\
\hline 3.5282 & 0.55 & 0.03638 & 2.60814 & 0.40214 & 0.072 \\
\hline
\end{tabular}


Table S4: $75 \mathrm{H}_{2}: 25 \mathrm{~N}_{2}$ voltage decay with respect to current density raw data for Figure $5 \mathrm{a}$.

\begin{tabular}{|c|c|c|c|c|c|c|c|c|c|}
\hline time (s) & $\begin{array}{c}\text { mean cell } \\
\text { voltage (V) }\end{array}$ & time (s) & $\begin{array}{c}\text { mean cell } \\
\text { voltage (V) }\end{array}$ & time (s) & $\begin{array}{c}\text { mean cell } \\
\text { voltage (V) }\end{array}$ & time (s) & $\begin{array}{c}\text { mean cell } \\
\text { voltage (V) }\end{array}$ & time (s) & $\begin{array}{l}\text { mean cell } \\
\text { voltage (V) }\end{array}$ \\
\hline 0 & 0.69733 & 0 & 0.68487 & 0 & 0.68488 & 0 & 0.63685 & 0 & 0.61845 \\
\hline 1.40308 & 0.69282 & 0.94604 & 0.68048 & 0.93405 & 0.67895 & 1.12207 & 0.62605 & 1.00104 & 0.60701 \\
\hline 1.8501 & 0.69161 & 1.5961 & 0.67733 & 1.52209 & 0.67181 & 1.42108 & 0.61563 & 1.5191 & 0.56688 \\
\hline 3.76819 & 0.68277 & 3.04117 & 0.64139 & 2.96317 & 0.51633 & & & & \\
\hline 4.38721 & 0.67355 & 3.4762 & 0.60593 & & & & & & \\
\hline 5.03729 & 0.65556 & 3.94922 & 0.54253 & & & & & & \\
\hline 5.79633 & 0.62243 & & & & & & & & \\
\hline 6.09235 & 0.60372 & & & & & & & & \\
\hline
\end{tabular}

Table S5: Calculated $75 \mathrm{H}_{2}: 25 \mathrm{~N}_{2}$ stack efficiency and power density raw data for Figure $5 \mathrm{~b}$.

\begin{tabular}{|c|c|c|c|c|c|}
\hline \multicolumn{3}{|c|}{$75 \mathrm{H}_{2}: 25 \mathrm{~N}_{2}$} & \multicolumn{3}{|c|}{$100 \% \mathrm{H}_{2}$} \\
\hline Current density & Stack efficiency & av. Power density $\left(\mathrm{W} \mathrm{cm}^{-2}\right)$ & Current density & Stack efficiency & av. Power density $\left(\mathrm{W} \mathrm{cm}^{-2}\right)$ \\
\hline 0.17778 & 0.4348 & 0.11736 & 0.17733 & 0.53504 & 0.1167 \\
\hline 0.22222 & 0.3954 & 0.14355 & 0.22179 & 0.52126 & 0.1422 \\
\hline 0.26667 & 0.399 & 0.16894 & 0.26622 & 0.50569 & 0.16559 \\
\hline 0.31111 & 0.3621 & 0.18844 & 0.31069 & 0.48819 & 0.18656 \\
\hline 0.35556 & 0.3519 & 0.20677 & 0.35511 & 0.47334 & 0.20675 \\
\hline
\end{tabular}


Table S6: Coefficient weighting raw data for Figure 6.

\begin{tabular}{|l|l|l|l|}
\hline coefficient & weighting & +error & -error \\
\hline X1 & -0.01235 & 0.0005185 & -0.0005185 \\
\hline X2 & 0.02503 & 0.0005185 & -0.0005185 \\
\hline X3 & 0.02868 & 0.0005185 & -0.0005185 \\
\hline X1X3 & 0.00193 & 0.0005185 & -0.0005185 \\
\hline X2X3 & -0.00531 & 0.0005185 & -0.0005185 \\
\hline X2X2 & -0.01449 & 0.0005185 & -0.0005185 \\
\hline
\end{tabular}

